\title{
FIGURATIVE LANGUAGE IN VIDEO OF COMEDY CENTRAL STAND-UP "LOSING ARGUMENTS WITH YOUR WIFE AFTER HER BRAIN SURGERY" BY JIM GAFFIGAN
}

\author{
Imam Maulana ${ }^{1}$, Muthia Mubasyira ${ }^{2}$ \\ ${ }^{1,2}$ Universitas Indraprasta PGRI, English Education Program, Campus A, Building 1, 2nd Floor \\ Jl. Nangka No. 58 C Kel. Tanjung Barat, Kec. Jagakarsa, Jakarta Selatan 12530, Jakarta, Indonesia. \\ Corresponding Author(S): muthia.mubasyira@yahoo.com
}

\begin{abstract}
:
In our daily life, we are using language to communicate with each other. A lot of linguistic aspects in a language, one of them is called figurative language. Figurative language is a word or phrase that has an isolated meaning from its exact definition. People usually use figurative language to emphasize or modify their sentences, so their sentences don't sound like something you often hear; making their sentences more unique has a lot of advantages, just imagine everyone using the same structure, emphasis, and the same emotion in their sentences, it's very horrible. Figurative language is also often used in stand-up comedy. Stand-up comedy is simply a single performed comedy actor in front of the audience.
\end{abstract}

Keywords: Figurative language, stand-up language comedy,

\section{INTRODUCTION}

Humans usually use language to communicate with each other. Language is various combinatorial frameworks people utilize most for communication. In this context, discrete means 'separate,' and combinatorial means 'ability to include together.' In our daily life, there are many ways to express an event, accident, or something, and figurative language is one of them. For example, you want to make a poem about the moon, so you can write 'the moon is smiling.' In this way, you make your readers are more into your poem, more intimate, more feeling, it also gives variously in your verse, so the readers are not easily bored.

Research by Afidah and Wahyudi (2014) stated that nowadays, many people like to listen to stand-up comedy. To give a context, someone who sings a song called 'singer,' someone who does stand-up comedy on the stage in front of the audience called 'comic.' There are many comics in this world. However, I choose Jim Gaffigan because he is the 'cleanest' comic in the world, so it's safe to bring his materials to the academic area.

Tarigan (1985) said that to display the sorts of metaphorical dialect and styles of meaning utilized in this time. Metaphorical dialects are categorized into four bunches, comparison, 
contradiction, attachment, and repetition. Most of the commonplace figurative language analyzed in this study are hyperbole, metaphor, personification, simile, etc. On the other hand, Keraf (2009:138) stated that "figurative language consists of sixteen kinds, they are Simile, Metaphor, allegory, Personification, Allusion, Eponym, Epithet, synecdoche, metonymy, Antonomasia, Hipflask or Hipalase, Irony, Satire, Innuendo, Antiphrasis, and Paronomasia," and Keraf (2009:129) stated that figurative language includes a work to clarify, fortify, a life, fortify, enhance a question. It gave the teachers and learners the advantage of centering on the figurative language in the classroom to provide students more various paths to express something in the learning process.

\section{METHOD}

\section{Qualitative}

According to Moleong (2010:6) Qualitative research is a scientific way to understand a phenomenon experienced by the object of research, such as nature, point of view, mobilization, and behavior. This qualitative technique helps analysts to complete articles, from sorting and researching data to making conclusions.

\section{Descriptive}

According to Sugiyono (2017:29), the descriptive method is a method to identify the independent variable in singular or plural form; we can use the descriptive method without comparing and relating it to other variables.

There are many related articles, but the analyst will bring three of them because of limited time. 1) Khairani, Dyas (2017) this research seeks about the figure of speech that Abdur used in his Stand-up comedy materials and its meaning. 2) Handika et al. (2019) studied figurative language in stand-up comedy performed by Hasan Minhaj and its meaning. 3) Hidayat, Didin (2019) this study is analyzing characteristics in a discourse that Russel Petters used in his stand-up comedy materials.

\section{RESULTS AND DISCUSSION}

The focus of this research is to sort out the figurative language in the Video of Comedy Central Stand-Up "Losing Arguments with Your Wife After Her Brain Surgery" by Jim Gaffigan. The analyst will rely on Keraf's (2009:138) perspective. Simile, Metaphor, allegory, Personification, Allusion, Eponym, Epithet, synecdoche, metonymy, Antonomasia, Hipflask or Hipalase, Irony, Satire, Innuendo, Antiphrasis, and Paronomasia.

Table 1 Results

\begin{tabular}{ccccc}
\hline \multirow{2}{*}{ Number } & $\begin{array}{c}\text { Figurative } \\
\text { Language }\end{array}$ & Example & Quantity & Percentage \\
\hline 1 & Simile & - & - & - \\
2 & Metaphor & - & - & - \\
3 & Allegory & - & - & - \\
\hline
\end{tabular}




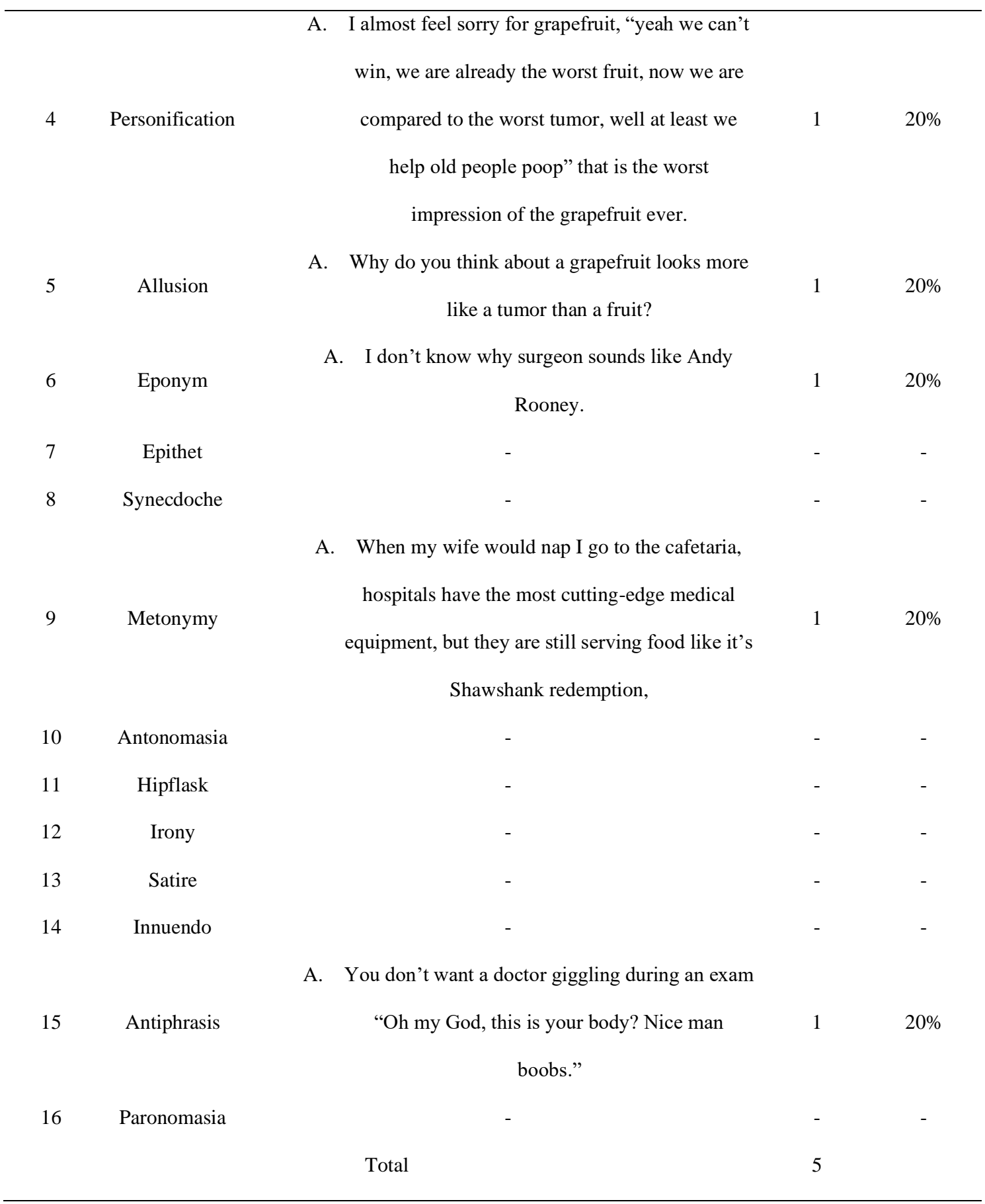




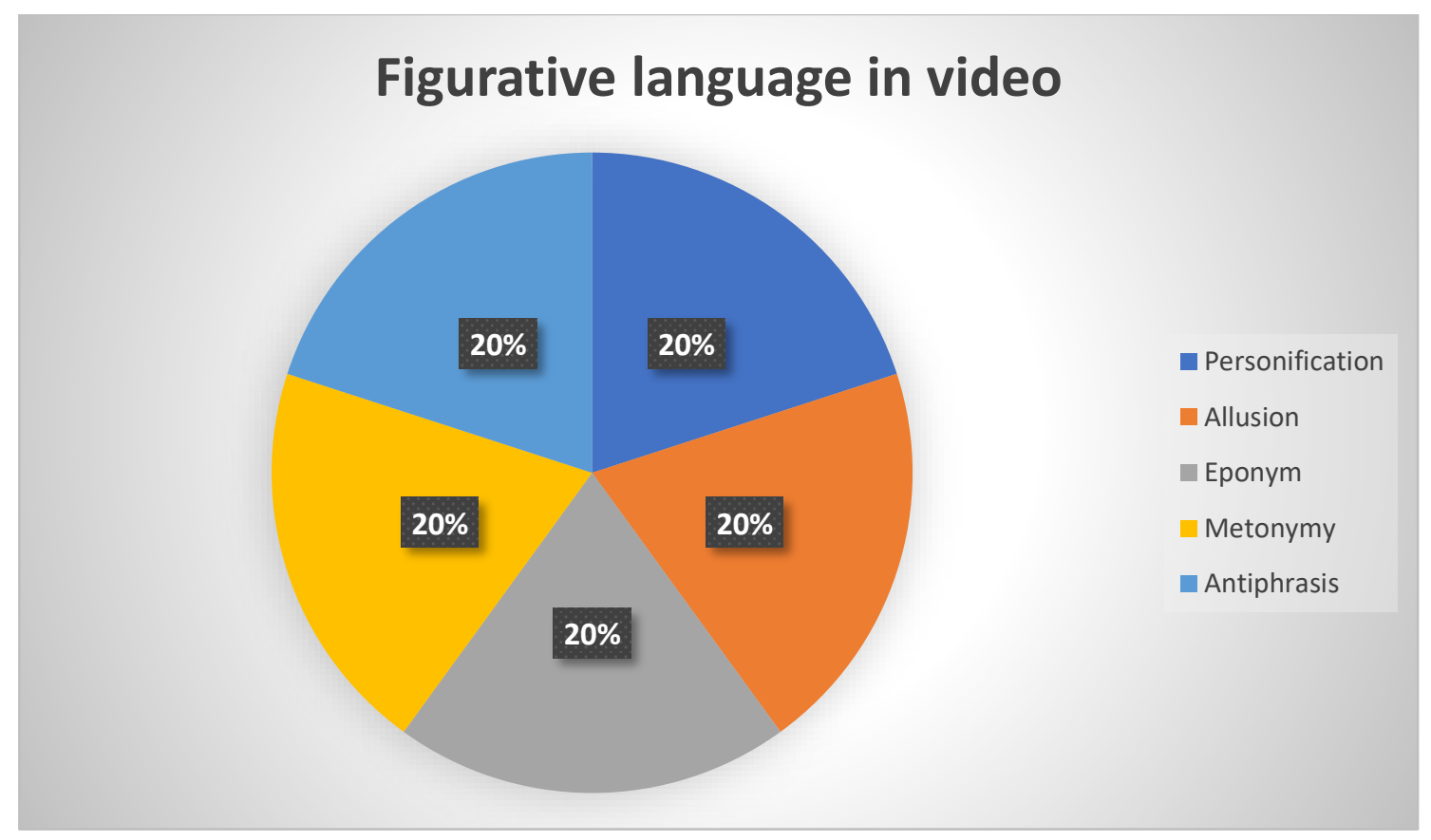

Figure 1 Example of Writing Caption in the Figure

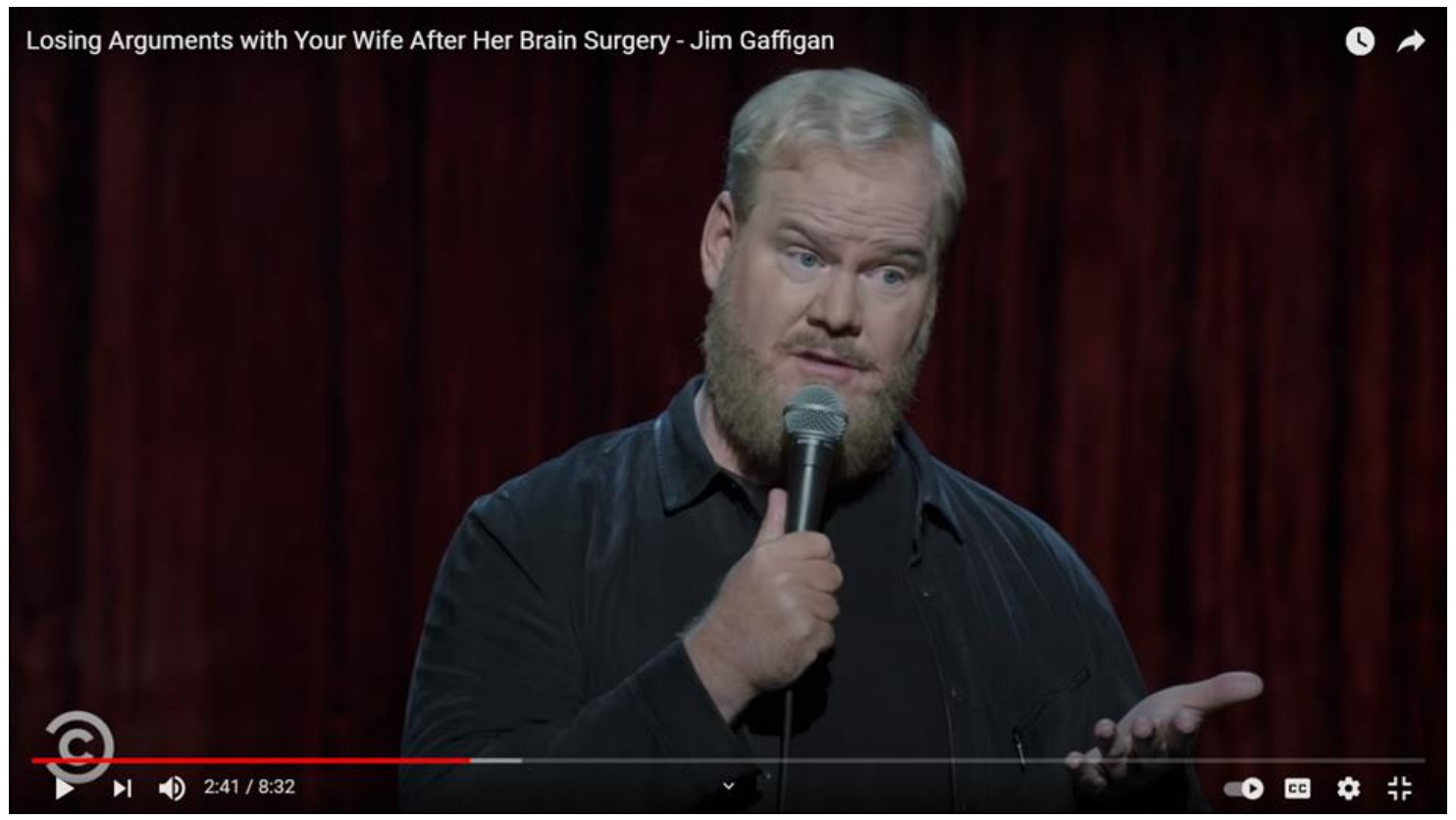

Figure 2 YouTube Printscreen

\section{CONCLUSION}

The results of this research are personification (20\%), allusion (20\%), eponym (20\%), metonymy (20\%), and antiphrasis (20\%). If we compared it with the research before, the first research showed that hyperbole (23\%), metaphor (14\%), simile $(8 \%)$, personification $(9 \%)$, etc. the second research showed that metaphor $(14 \%)$, simile $(12 \%)$, metonymy $(12 \%)$, irony $(5 \%)$, etc. the result of this research is not various, because the analyst only 
took it from one video which is eight-minute length, because of limited time. The analyst hopes that this research can add different value to the academic resource.

\section{ACKNOWLEDGMENT}

Thank you to everyone who has participated in this article. First, to Almighty God, for the blessings. To my family, for all the supports. To my lecturer Mrs. Muthia Mubasyira, S.Hum. I really appreciate them for their help and support.

\section{REFERENCE}

Anon. (n.d). Analisis diksi dan gaya bahasa audisi stand up comedy Dodit Mulyanto.

Manuaba, I. B. A. L., \& Sudirman, I. N. (2019). A literary analysis on figure of speech in kakawin nitisastra. Yavana Bhasha: Journal of English Language Education, 1(2).

Handika, D., Syarif, H., \& Marlina, L. (2019). An analysis of minor figurative language used in stand-up comedy performed by Hasan Minhaj entitled homecoming king. English Language and Literature, 8(4).

Comedy Central Stand-Up. (2018). Losing arguments with your wife after her brain surgery - Jim Gaffigan. Diambil dari https://www.youtube.com/watch?v=UVDYXB-der0\&t=4s 